\title{
The Trans-Alaska Pipeline System Facilitates Shrub Establishment in Northern Alaska
}

\author{
Rosemary A. Dwight ${ }^{1,2}$ and David M. Cairns ${ }^{1}$
}

(Received 2 February 2018; accepted in revised form 22 May 2018)

\begin{abstract}
The Arctic tundra is undergoing many environmental changes in addition to increasing temperatures: these changes include permafrost degradation and increased shrubification. Disturbances related to infrastructure can also lead to similar environmental changes. The Trans-Alaska Pipeline System (TAPS) is an example of infrastructure that has made a major imprint on the Alaskan landscape. This paper assesses changes in shrub presence along the northernmost $255 \mathrm{~km}$ of the TAPS. We used historical satellite imagery from before construction of the TAPS in 1974 and contemporary satellite imagery from 2010 to 2016 to examine changes in shrub presence over time. We found a 51.8\% increase in shrub presence adjacent to the pipeline compared to $2.6 \%$ in control areas. Additionally, shrub presence has increased significantly more in areas where the pipeline is buried, indicating that the disturbances linked to pipeline burial have likely created favorable conditions for shrub colonization. These results are important for predicting potential responses of tundra vegetation to disturbance, which will be crucial to forecasting the future of Arctic tundra vegetation.
\end{abstract}

Key words: shrub expansion; Arctic change; tundra; Trans-Alaska Pipeline System; permafrost; disturbance

RÉSUMÉ. La toundra de l'Arctique fait l'objet de nombreux changements environnementaux, sans compter que les températures augmentent. Ces changements touchent notamment la dégradation du pergélisol et l'intensification des arbustaies. Les perturbations découlant des infrastructures peuvent également entraîner des changements environnementaux semblables. Le réseau pipelinier transalaskien (TAPS) est un exemple d'infrastructure qui a laissé d'importantes traces sur le paysage de l'Alaska. Dans cet article, nous abordons les changements concernant les arbustes sur le tronçon de $255 \mathrm{~km}$ le plus au nord du TAPS. Nous nous sommes servis d'images satellitaires historiques datant d'avant la construction du TAPS en 1974 ainsi que d'images satellitaires contemporaines pour la période allant de 2010 à 2016 pour examiner les changements caractérisant les arbustes au fil des ans. Nous avons constaté une augmentation de $51,8 \%$ pour ce qui est de la présence d'arbustes adjacents au pipeline, comparativement à $2,6 \%$ dans les aires de contrôle. De plus, la présence d'arbustes a augmenté beaucoup plus là où le pipeline est enfoui sous la terre, ce qui indique que les perturbations liées à l'enfouissement du pipeline ont vraisemblablement créé des conditions favorables à l'établissement d'arbustes. Ces résultats jouent un grand rôle dans la prévision des réactions éventuelles de la végétation de la toundra aux perturbations, ce qui est crucial en matière de prévision de l'état futur de la végétation de la toundra de l'Arctique.

Mots clés : intensification des arbustaies; changement de l'Arctique; toundra; réseau pipelinier transalaskien; pergélisol; perturbation

Traduit pour la revue Arctic par Nicole Giguère.

\section{INTRODUCTION}

The Arctic is experiencing warming at more than two times the mean global rate (IPCC, 2007), a process known as "Arctic Amplification." Increases in regional temperatures are expected to result in widespread permafrost degradation (thermokarst), especially in areas where ground temperatures are close to freezing (Jorgenson et al., 2006; Shur and Jorgenson, 2007; Grosse et al., 2011). Ice-rich permafrost is an important factor that controls the responses of Arctic systems to disturbance (Walker and Walker, 1991). If thermokarst is initiated on a large scale, it can take up to 30 years after the disturbance for stabilization to occur in ice-rich, unstable thaw areas (Lawson, 1986; Walker and Walker, 1991).

Disturbance to the surface in permafrost terrain results in a disruption of the thermal equilibrium, which can lead to increased thaw (Brown, 1997). Since the base of the active layer is impermeable to water and impenetrable to roots (NRC, 2003), permafrost warming and degradation changes the hydrological and nutritional characteristics of soils, which affect vegetation distribution, plant community structure, and productivity in Arctic and Subarctic regions (Reynolds and Tenhunen, 1996; Lloyd et al., 2003;

\footnotetext{
${ }^{1}$ Department of Geography, Texas A\&M University, 810 Eller O\&M Building, Mailstop 3147 TAMU, College Station, Texas 77843-3147, USA

${ }^{2}$ Corresponding author: radwight@tamu.edu

(C) The Arctic Institute of North America
} 
Christensen, 2004). Thus, temperature changes affect both permafrost regimes and the related changes in hydrology and vegetation (Christensen, 2004).

Increasing productivity of Arctic vegetation in response to recent climate warming has been well documented (Goetz et al., 2005; Jia et al., 2006; Stow et al., 2007). A major component of these increases can be attributed to increases in deciduous shrub cover (shrubification), mostly Betula, Salix, and Alnus species (Myers-Smith et al., 2011a; Naito and Cairns, 2015), which may also be influenced by the permafrost regime. In turn, shrubification has the potential to affect many components of tundra ecosystems, such as the surface energy balance, hydrology, nutrient cycling, snow depth, and albedo (Swann et al., 2010; Naito and Cairns, 2011b; Pearson et al., 2013; MyersSmith et al., 2015). Permafrost is not directly connected to the atmosphere because the influences of topography, groundwater, soil properties, vegetation, snow, and the interactions of these factors can result in positive or negative feedbacks to permafrost stability (Jorgenson et al., 2010). While permafrost plays an important role in shaping vegetation patterns, vegetation cover also has the potential to reduce permafrost degradation (Yi et al., 2007). However, there is still uncertainty regarding the relationship between shrub expansion and active-layer dynamics (Frost et al., 2018).

In Alaska, the discovery of oil at Prudhoe Bay in 1968 initiated the start of major industrial activity and environmental research in the Arctic (Walker and Walker, 1991). The Trans-Alaska Pipeline System (TAPS) was constructed over a period of three years, concluding in 1977, to move oil over $1287 \mathrm{~km}$ from Prudhoe Bay to the port of Valdez in a $1219 \mathrm{~mm}$ diameter pipeline (Brown and Kreig, 1983; Hall et al., 2003). The TAPS has made a significant imprint on the landscape: oilfield infrastructure on the North Slope of Alaska covers an area of 7429 ha (Walker et al., 1987a; Walker and Walker, 1991; Raynolds et al., 2014).

Infrastructure in permafrost terrain can cause groundice degradation by the structure itself or by modifying the subsurface conditions during the construction process (Bommer et al., 2010). Lawson (1986) found that ice-rich areas disturbed by exploratory drilling activities in the National Petroleum Reserve-Alaska took more than 30 years to stabilize to a point that would allow for vegetation growth and thermal equilibrium, whereas areas with icepoor materials stabilized within 5 to 10 years. Although pipeline burial is the preferred method of construction for such infrastructure in nonpolar environments, this method can cause problems in permafrost regions because the subsurface heat from the transmission of the warm fluids results in permafrost thaw in the soils surrounding the pipeline and differential settlement (NRC, 2003). The Arctic Foothills and Arctic Coastal Plain are mostly underlain by deep continuous permafrost, with unfrozen areas mostly limited to deep river channels and deep lake basins (Brown and Berg, 1980). Since pipeline burial requires thaw-stable conditions, $57 \%$ of the pipeline north of the Yukon River was constructed aboveground (Brown and Berg, 1980; Brown and Kreig, 1983). Following disturbance from the pipeline construction, thaw depths increased for at least the subsequent three years, reaching depths $28 \mathrm{~cm}$ greater along the oil pipeline than at control sites (Reynolds and Tenhunen, 1996).

The thermal stability of a disturbed area determines the timeframe for vegetation recovery, as well as the type of vegetation that is able to colonize a site (Walker and Walker, 1991). Most studies have emphasized the environmental impacts of roads, gravel sites, and the Prudhoe Bay Oil Field (e.g., Johnson, 1987; Walker et al., 1987a); however, a survey of published literature reveals that little is known about the current response of vegetation to the disturbance of the pipeline across the wide range of environments it traverses. Following construction of the TAPS, the Alyeska Pipeline Service Company attempted revegetation using a seed mix of grasses (Johnson, 1981). Initially, the revegetation process along the TAPS was found to be very slow (Walker et al., 1987b). At the time of the study by Johnson (1981), revegetation on disturbed areas by native species was limited, and establishment of Salix pulchra and Betula nana cuttings also had limited success. Some revegetated areas were dominated by grass cover from the seed mix of exotic species; the potential impact of their effects on native species revegetation was not known at the time (Johnson, 1981). The restoration of disturbed sites is often slow; however, even so, it has been found that revegetation can occur naturally (Forbes and Jefferies, 1999). Since gravel pads are akin to riparian gravel bars, it is likely that riparian species will be more successful in colonizing gravel pads (Bishop and Chapin, 1989). At present, natural colonizers that are well adapted to well-drained, nutrient-poor soils have become the dominant species along the TAPS (Jorgenson, 1997). However, we still have much to learn regarding the impacts of energy development on the processes of tundra ecosystems and how best to rehabilitate these ecosystems (Reynolds and Tenhunen, 1996).

Here, we aimed to assess the state of shrub presence along the TAPS north of the Brooks Range, Alaska. Our objectives were to determine (1) whether shrub presence has increased more near the pipeline than in adjacent undisturbed areas, and (2) whether the placement of the pipeline (aboveground or buried) has an impact on shrub presence.

\section{METHODS}

\section{Study Area}

The North Slope of Alaska is the $230000 \mathrm{~km}^{2}$ area north of the crest of the Brooks Range. This area is divided into three regions: the Arctic Coastal Plain, the Arctic Foothills, and the Brooks Range. The North Slope is underlain 


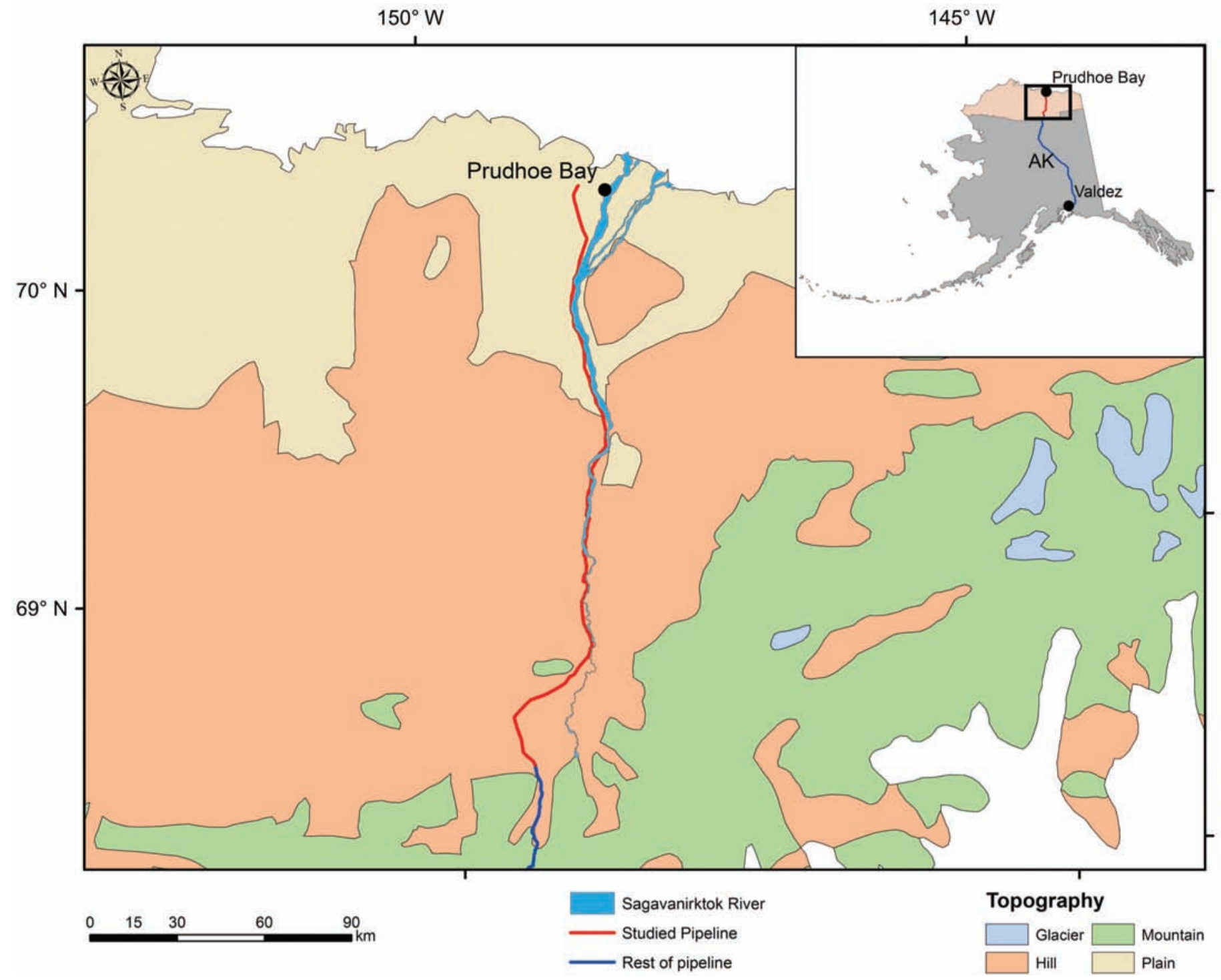

FIG. 1. Path of the section of the pipeline studied, including topography and the Sagavanirktok River. Topographical data from Raynolds and Cooper (2016).

by continuous permafrost ( $>90 \%$ coverage), and sedge tussocks and shrubs characterize the tundra vegetation. The most common shrub species are birch (Betula nana and B. glandulosa), willow (Salix alaxensis, $S$. pulchra, and $S$. glauca), and alder (Alnus crispa) (Tape et al., 2006). Most of the oil activities are constrained to the Arctic Coastal Plain; however, the TAPS corridor stretches $1287 \mathrm{~km}$ from Prudhoe Bay in the north to Valdez in the south (Fig. 1).

\section{Satellite Image Acquisition and Analysis}

Digital scans of historical black-and-white images from 21 June 1974, captured by the Keyhole satellite system (KH-9) with a high spatial resolution of 2-4 feet, were acquired from the U.S. Geological Survey Earth Resources Observation and Science Center. The historical images were co-registered to the contemporary images using ArcMap 10.5. The contemporary panchromatic images for the entire $255 \mathrm{~km}$ section were sourced from the DigitalGlobe archives (DigitalGlobe, Inc., USA). The contemporary images were captured in June to September of $2010-16$ by the Worldview-1 $(0.5 \mathrm{~m})$, Worldview-2 $(0.46 \mathrm{~m})$, Worldview-3 $(0.31 \mathrm{~m})$, and GeoEye-1 $(0.41 \mathrm{~m})$ satellites (DigitalGlobe, Inc., USA). Images were selected for lack of cloudiness and snow. The pipeline was classified as either "aboveground" or "buried," with a total of $110 \mathrm{~km}$ of pipeline aboveground and $115 \mathrm{~km}$ of buried pipeline. Transects that were located over gravel pads or rivers were marked as "obstructed" and excluded from analysis.

To address the first objective, five control lines not affected by the TAPS were used to determine whether the increase in shrub presence over time was greater along the pipeline than in the adjacent tundra (Fig. 2). Control lines were placed parallel to the pipeline; every effort was made to put the control lines in settings similar to those of the adjacent pipeline. Where possible, this was done by placing the control lines on the opposite side of the Sagavanirktok River and at a similar distance from the river as the 

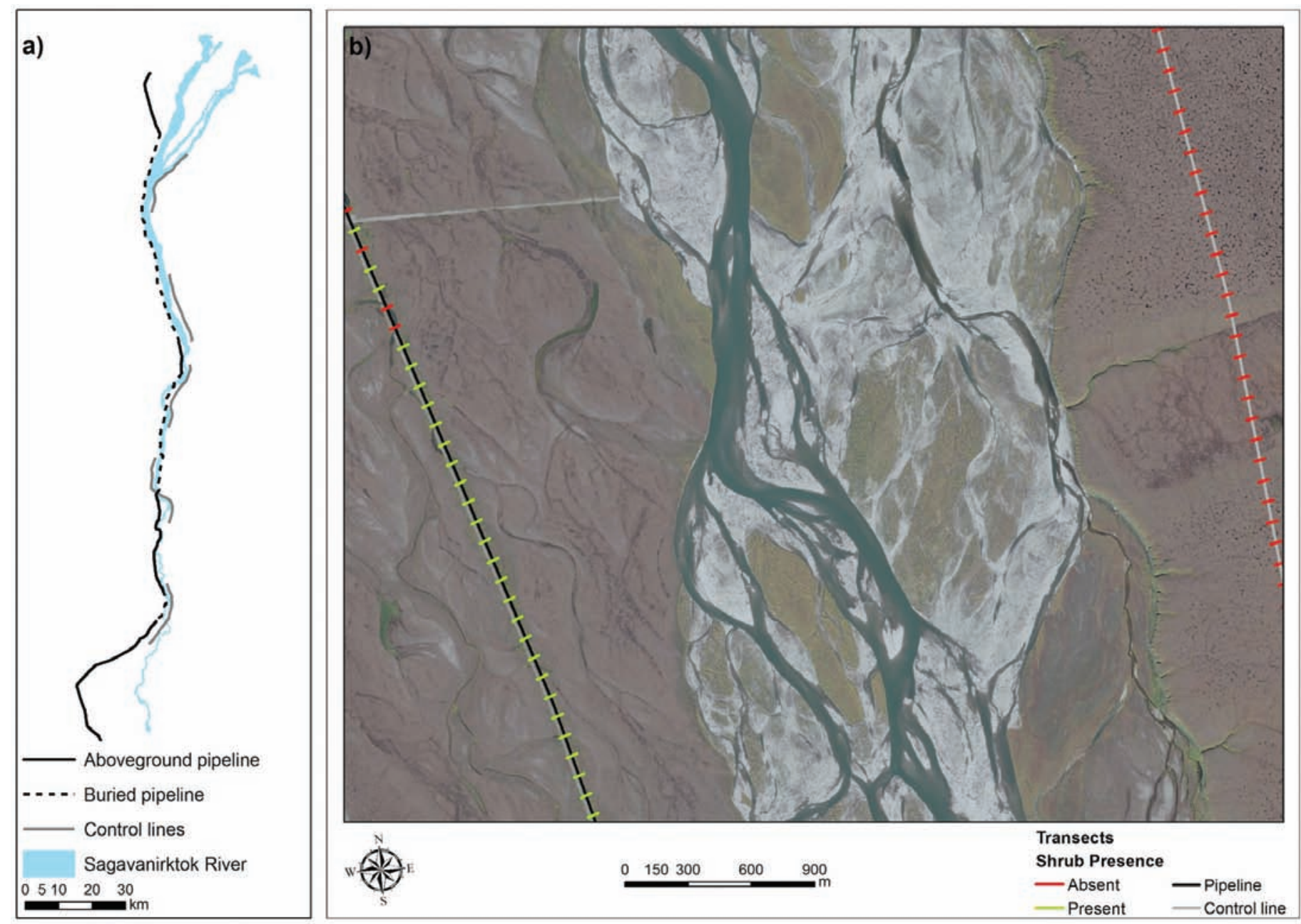

FIG. 2. a) The path of the pipeline and control lines in relation to the Sagavanirktok River. b) Example of the pipeline and a control line with sample transects from WorldView-2 imagery (C 2016 Digital Globe, Inc.).

pipeline was at that point (Fig. 2). Transects $50 \mathrm{~m}$ wide and perpendicular to the line were created at $100 \mathrm{~m}$ intervals along the pipeline and control lines, using ArcMap 10.5. The transects were manually classified according to whether they intersected shrub cover or not, limiting classification to the presence or absence of tall shrubs. We recorded shrub presence (" 1 ") or absence ("0") along 1090 transects on the control lines of both the historical and contemporary imagery. We then repeated this process using 1037 transects at parallel points along the pipeline to assess change in shrub presence over time (e.g., Fig. 3). To quantify the contemporary association between the pipeline burial status and shrub presence for objective two, we classified a total of 2155 transects along the $255 \mathrm{~km}$ of studied pipeline for shrub presence ("1") or absence ("0"). Any transects intersecting a gravel pad, river or lake were omitted from the analysis.

\section{Statistical Analysis}

Change detection was conducted by subtracting the historical classification values from the contemporary classification values. Values of "-1" represented a loss in shrub presence, " 0 " indicated no change, and " +1 " indicated shrub presence along a transect where there was none previously. Pearson's chi-squared test with Yate's continuity correction was used to test for the association between shrub presence and pipeline burial status.

\section{RESULTS}

\section{Changes in Shrub Presence over Time}

In the control areas, a total of 67 of the 1090 transects (6.1\%) intersected shrubs in the historical imagery. Of the 1090 transects, only 29 (2.6\%) transitioned from "no shrub" in the historical imagery to "shrub" in the contemporary imagery (Fig. 4). Along the pipeline, 95 of the 1037 (9.2\%) transects intersected shrubs in the historical imagery. A greater increase in shrub presence was found in the vicinity of the pipeline; of the 1037 transects, 602 (58.1\%) transitioned from "no shrub" to "shrub" in the contemporary imagery. A total of $29.6 \%$ of the sampled 

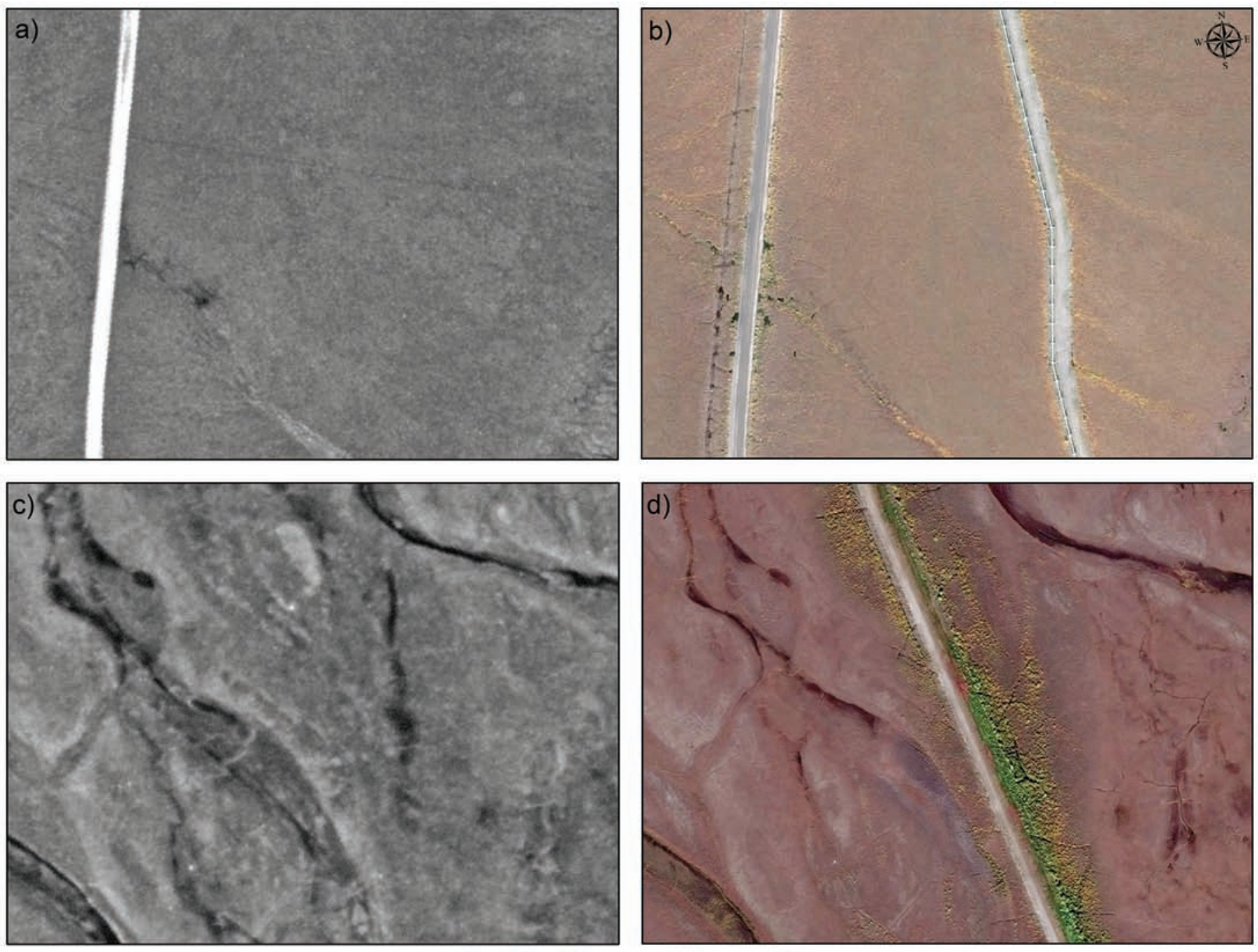

50100

200

300

FIG. 3. a) Historical image of a location where a pipeline was later constructed aboveground. b) Contemporary image of that aboveground pipeline, from WorldView-2 imagery (C 2016 Digital Globe, Inc.). The straight line at the left of both images is the Dalton Highway. c) Historical image of a location where a pipeline was later buried. d) Contemporary image of that same location with buried pipeline, from WorldView-2 (C 2016 Digital Globe, Inc.).

transects transitioned from "no shrub" to "shrub" (Fig. 4). None of the sampled transects lost the presence of shrub cover along the control transects over time; however, one pipeline transect transitioned from having shrub cover in the historical imagery to not having shrubs in the contemporary imagery.

\section{Relationship between Shrub Presence and Pipeline Burial Status}

In areas where the pipeline is aboveground, only $14.9 \%$ of the transects transitioned from "no shrub" to "shrub" (Fig. 4). In areas where the pipeline is buried, $70.2 \%$ of the transects transitioned from "no shrub" to "shrub" (Fig. 4).

Chi-squared analysis was conducted to test for an association between pipeline burial status and shrub presence along the entire $255 \mathrm{~km}$ of pipeline north of the Brooks Range. The associations, as seen in Table 1, yielded a highly significant relationship $\left(\chi^{2}=1078.2\right.$, $p<0.01$ ) between shrub occurrence and pipeline burial status. This indicates that shrubs are more likely to establish in areas where the pipeline is buried than in cases where is it aboveground.

\section{DISCUSSION}

\section{Change over Time}

This study found that shrub presence increased by $58.1 \%$ in the vicinity of the pipeline, as opposed to $2.7 \%$ for the control transects, which suggests that the processes linked to the disturbance from the pipeline have facilitated shrub colonization. While shrub expansion in the Arctic has been widely reported, certain areas are more susceptible to shrub encroachment (Sturm et al., 2001; Tape et al., 


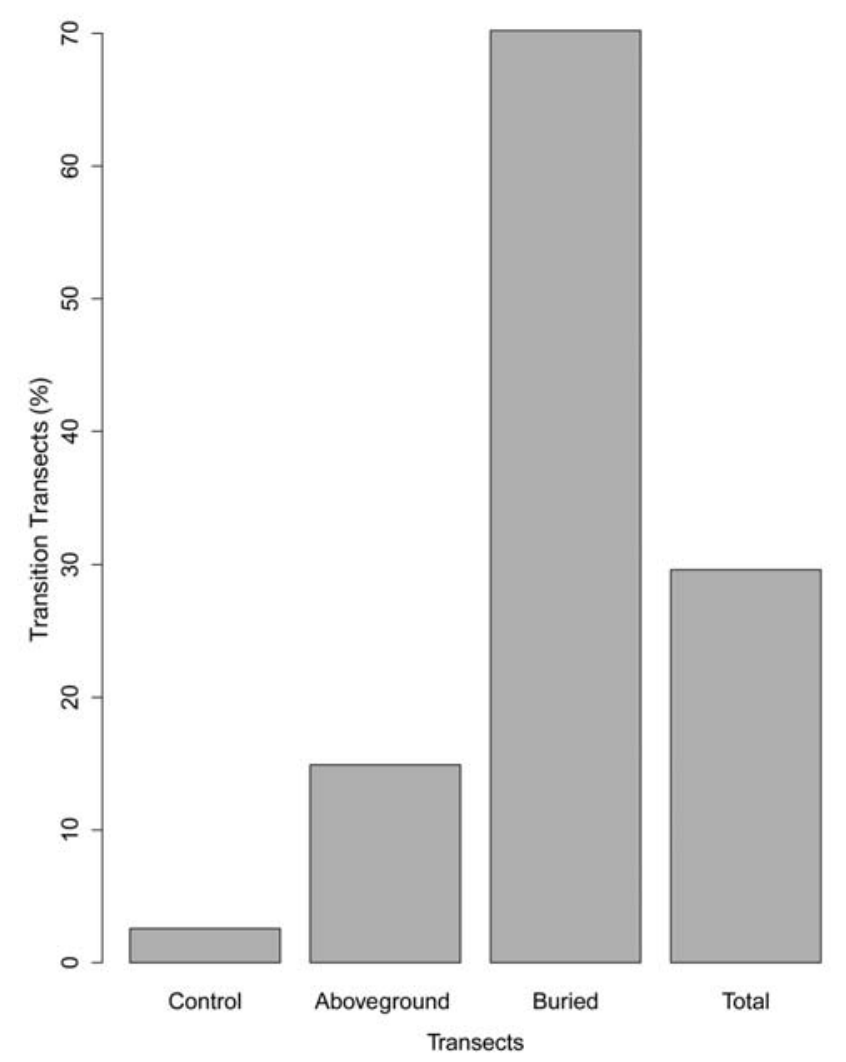

FIG. 4. Influence of pipeline burial on shrub presence. Graph shows the percentage of transects (control, aboveground pipeline, buried pipeline, and total) that transitioned from absence of shrubs in the historical imagery to shrub presence in the contemporary imagery.

TABLE 1. Associations between shrub presence and pipeline burial status, expressed in number of transects.

\begin{tabular}{lccc}
\hline \hline Pipeline burial status & No shrubs & Shrubs present & Total \\
\hline Aboveground & 958 & 132 & 1090 \\
Buried & 183 & 882 & 1065 \\
Total & 1141 & 1014 & 2155 \\
\hline \hline
\end{tabular}

2006; Hallinger et al., 2010; Myers-Smith et al., 2011b; Naito and Cairns, 2011a, 2015; Elmendorf et al., 2012b; Frost et al., 2013; Ackerman et al., 2017; Martin et al., 2017; Myers-Smith and Hik, 2017). The percent increase in shrub presence along the control transects is relatively low compared to some of the rates published in the studies listed above, which indicates that local conditions play a major role in facilitating shrub expansion (e.g., Tape et al., 2006; Myers-Smith et al., 2011b; Naito and Cairns, 2011b, 2015; Ackerman et al., 2017). Jorgenson et al. (2015) found that even though shrub expansion rates were relatively low for the region of northwest Alaska as a whole, they were highly variable according to ecotype and biophysical drivers. Favorable local conditions include floodplains, areas with higher topographic wetness index values (Naito and Cairns, 2011b), and frost-heaved soils (Frost et al., 2013). The disturbance of the ground from the TAPS construction process, and the pipeline itself could create similar conditions to the favorable conditions that occur naturally, and hence, facilitate shrub colonization.

\section{Influence of the Pipeline}

While we found that increases in shrub presence were greatest in the vicinity of the pipeline, these results were not uniform along its entire length. A significant relationship $(p<0.01)$ between shrub presence and pipeline burial status was found. This relationship is highly evident in Figure 5, with sharp changes even occurring where the pipeline transitions from being aboveground to buried. Processes linked to the disturbance from construction and the pipeline itself have likely created favorable conditions for recruitment. The buried pipeline increases the adjacent active layer thickness (Reynolds and Tenhunan, 1996), which will likely allow for greater moisture throughflow and rooting depths. Chapin and Shaver (1981) found that plants in areas affected by disturbance from vehicles had improved nutrient status (and therefore, high productivity); however, they concluded that this result could not be attributed solely to increases in soil temperature and thaw depth. Gill et al. (2014) found that the environmental changes associated with road construction facilitated alder growth and recruitment along the Dempster Highway in the Northwest Territories, Canada. Such changes can include altered surface energy balance, ground thermal properties, and the temperature regime of the underlying permafrost (Forbes and Jefferies, 1999; Forbes et al., 2001; Gill et al., 2014). A study by Ackerman and Breen (2016) notes four stands of Populus tremuloides on abandoned gravel roads and pads in the northern foothills of the Brooks Range, Alaska, which is north of the species' range. The authors attribute their presence to the favorable conditions created by the pads: increased rooting depth, well-drained microsites, an extended growing season, and acid-buffering capacity (Ackerman and Breen, 2016). Without ground observations it is beyond the scope of this study to posit the exact mechanism driving increased shrub growth along the pipeline (particularly where it is buried). However, like Gill et al. (2014) and Ackerman and Breen (2016), we suggest that the recruitment of new individuals along the pipeline is likely due to the creation of more favorable conditions, probably in the form of deeper rooting depths, well-drained microsites, and increased nutrient availability.

\section{Implications}

Shrub expansion is limited by local conditions. Disturbance is therefore an important factor influencing shrub presence and may even have a greater influence than climate warming in the recruitment of new individuals (Myers-Smith et al., 2011b). Shrub cover linked to disturbance can influence other parts of systems through feedbacks. Shrub proliferation along roads in the Canadian tundra resulted in a positive feedback cycle through 


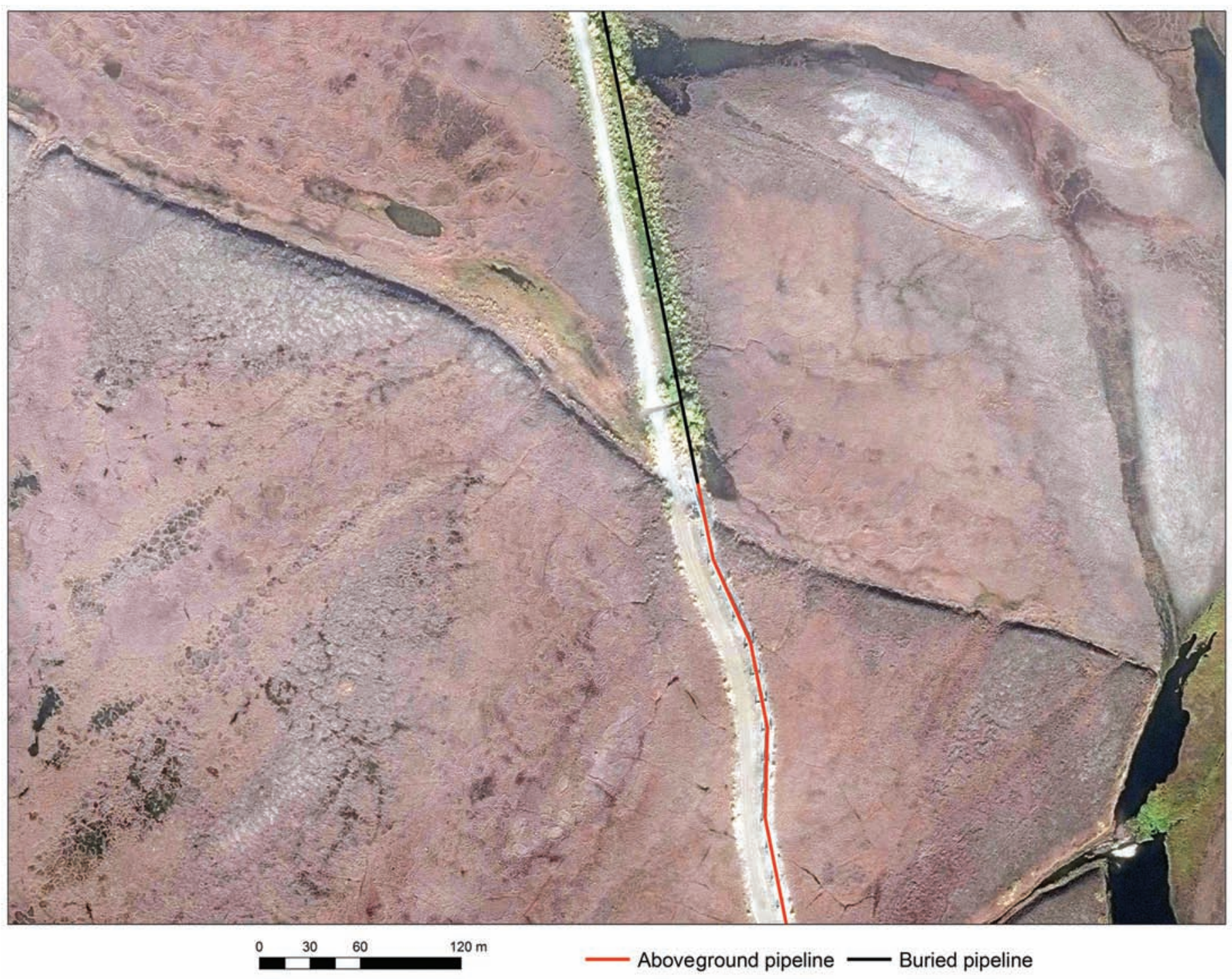

FIG. 5. Image from WorldView-3 (C) 2016 Digital Globe, Inc.) showing the abrupt change in vegetation along the pipeline as it transitions from aboveground (red) to buried (black).

increased snow accumulation, altered ground temperatures, and soil chemistry (Gill et al., 2014). In areas where tall shrubs were not as established, not as much snow and dust accumulated; therefore, the feedbacks were not as pronounced (Gill et al., 2014). Positive feedbacks similar to those observed by Gill et al. (2014) could be expected along the pipeline in places where shrubs trap the snow, increasing snow depth. This positive feedback could have significant implications for the stability and integrity of infrastructure in tundra environments. It is essential to obtain better knowledge of how Arctic tundra vegetation recovers from disturbance to provide an idea of its potential responses to future disturbances, which are likely to become more frequent (Chapin et al., 2005; Cray and Pollard, 2015).

\section{CONCLUSIONS}

This study has shown that shrub colonization has been facilitated by processes linked to the disturbance of the TAPS. Identifying which factors are responsible for the recruitment of new individuals is imperative to quantify the impact of shrub expansion on the Arctic tundra ecosystems (Myers-Smith et al., 2011b). While this study cannot definitively identify the causes of shrubification, the correlation between shrub presence and the disturbance of the pipeline provides useful knowledge of how the vegetation has responded, with shrubs exploiting disturbed areas. Understanding the responses of tundra to disturbance and characterizing the vulnerability of the Low Arctic to tall shrub and tree expansion is critical for projecting possible feedbacks (Elmendorf et al., 2012a; Frost and Epstein, 2014). The findings of this study align with other Arctic studies (e.g., Gill et al., 2014; Ackerman and Breen, 2016); therefore, this study will contribute to 
obtaining a better understanding of the cumulative effects of anthropogenic disturbances and how the Arctic tundra environment may respond to continued disturbances.

\section{ACKNOWLEDGEMENTS}

The financial assistance of the National Research Foundation (NRF) towards this research is hereby acknowledged. Opinions expressed and conclusions arrived at are those of the authors and are not necessarily to be attributed to the NRF. Geospatial support for this work was provided by the Polar Geospatial Center under NSF-OPP awards 1043681 and 1559691. We would also like to thank the three anonymous reviewers whose feedback served to improve this paper.

\section{REFERENCES}

Ackerman, D., and Breen, A. 2016. Infrastructure development accelerates range expansion of trembling aspen (Populus tremuloides, Salicaceae) into the Arctic. Arctic 69(2):130-136. https://doi.org/10.14430/arctic4560

Ackerman, D., Griffin, D., Hobbie, S.E., and Finlay, J.C. 2017. Arctic shrub growth trajectories differ across soil moisture levels. Global Change Biology 23(10):4294-4302. https://doi.org/10.1111/gcb.13677

Bishop, S.C., and Chapin, F.S., III. 1989. Patterns of natural revegetation on abandoned gravel pads in Arctic Alaska. Journal of Applied Ecology 26(3):1073-1081.

https://doi.org/10.2307/2403713

Bommer, C., Phillips, M., and Arenson, L.U. 2010. Practical recommendations for planning, constructing and maintaining infrastructure in mountain permafrost. Permafrost and Periglacial Processes 21(1):97-104.

https://doi.org/10.1002/ppp.679

Brown, J. 1997. Disturbance and recovery of permafrost terrain. In: Crawford, R.M., ed. Disturbance and recovery in Arctic lands: An ecological perspective. Dordrecht: Springer. $167-178$.

Brown, J., and Berg, R.L., eds. 1980. Environmental engineering and ecological baseline investigations along the Yukon RiverPrudhoe Bay Haul Road. CRREL Report 80-19. Hanover, New Hampshire: Cold Regions Research and Engineering Laboratory.

Brown, J., and Kreig, R., eds. 1983. Guidebook to permafrost and related features along the Elliott and Dalton Highways, Fox to Prudhoe Bay, Alaska. Fairbanks: Alaska Division of Geological \& Geophysical Surveys, Department of Natural Resources.

Chapin F.S., III, and Shaver, G.R. 1981. Changes in soil properties and vegetation following disturbance of Alaskan Arctic tundra. Journal of Applied Ecology 18(2):605-617.
Chapin, F.S., III, Sturm, M., Serreze, M.C., McFadden, J.P., Key, J.R., Lloyd, A.H., McGuire, A.D., et al. 2005. Role of land-surface changes in Arctic summer warming. Science 310(5748):657-660. https://doi.org/10.1126/science.1117368

Christensen, T.R., Johansson, T., Åkerman, H.J., Mastepanov, M., Malmer, N., Friborg, T., Crill, P., and Svensson, B.H. 2004. Thawing sub-Arctic permafrost: Effects on vegetation and methane emissions. Geophysical Research Letters 31(4), L04501. https://doi.org/10.1029/2003gl018680

Cray, H.A., and Pollard, W.H. 2015. Vegetation recovery patterns following permafrost disturbance in a Low Arctic setting: Case study of Herschel Island, Yukon, Canada. Arctic, Antarctic, and Alpine Research 47(1):99-113.

https://doi.org/10.1657/AAAR0013-076

Elmendorf, S.C., Henry, G.H.R., Hollister, R.D., Björk, R.G., Bjorkman, A.D., Callaghan, T.V., Collier, L.S., et al. 2012a. Global assessment of experimental climate warming on tundra vegetation: Heterogeneity over space and time. Ecology Letters 15(2):164-175. https://doi.org/10.1111/j.1461-0248.2011.01716.x

Elmendorf, S.C., Henry, G.H.R., Hollister, R.D., Björk, R.G., Boulanger-Lapointe, N., Cooper, E.J., Cornelissen, J.H.C., et al. 2012b. Plot-scale evidence of tundra vegetation change and links to recent summer warming. Nature Climate Change 2(6):453-457.

https://doi.org/10.1038/nclimate1465

Forbes, B.C., and Jefferies, R.L. 1999. Revegetation of disturbed Arctic sites: Constraints and applications. Biological Conservation 88(1):15-24. https://doi.org/10.1016/S0006-3207(98)00095-0

Forbes, B.C., Ebersole, J.J., and Strandberg, B. 2001. Anthropogenic disturbance and patch dynamics in circumpolar Arctic ecosystems. Conservation Biology 15(4):954-969. https://doi.org/10.1046/j.1523-1739.2001.015004954.x

Frost, G.V., and Epstein, H.E. 2014. Tall shrub and tree expansion in Siberian tundra ecotones since the 1960s. Global Change Biology 20(4):1264-1277. https://doi.org/10.1111/gcb.12406

Frost, G.V., Epstein, H.E., Walker, D.A., Matyshak, G., and Ermokhina, K. 2013. Patterned-ground facilitates shrub expansion in Low Arctic tundra. Environmental Research Letters 8(1), 015035. https://doi.org/10.1088/1748-9326/8/1/015035

- 2018. Seasonal and long-term changes to active-layer temperatures after tall shrubland expansion and succession in Arctic tundra. Ecosystems 21(3):507-520. https://doi.org/10.1007/s10021-017-0165-5

Gill, H.K., Lantz, T.C., O'Neill, B., and Kokelj, S.V. 2014. Cumulative impacts and feedbacks of a gravel road on shrub tundra ecosystems in the Peel Plateau, Northwest Territories, Canada. Arctic, Antarctic, and Alpine Research 46(4):947-961. https://doi.org/10.1657/1938-4246-46.4.947 
Goetz, S.J., Bunn, A.G., Fiske, G.J., and Houghton, R.A. 2005. Satellite-observed photosynthetic trends across boreal North America associated with climate and fire disturbance. Proceedings of the National Academy of Sciences 102(38):13521 - 13525.

https://doi.org/10.1073/pnas.0506179102

Grosse, G., Romanovsky, V., Jorgenson, T., Anthony, K.W., Brown, J., and Overduin, P.P. 2011. Vulnerability and feedbacks of permafrost to climate change. Eos, Transactions American Geophysical Union 92(9):73-74. https://doi.org/10.1029/2011EO090001

Hall, W.J., Nyman, D.J., Johnson, E.R., and Norton, J.D. 2003. Performance of the Trans-Alaska Pipeline in the November 3, 2002 Denali fault earthquake. In: Beavers, J.E., ed. Advancing mitigation technologies and disaster response for lifeline systems. $522-534$.

Hallinger, M., Manthey, M., and Wilmking, M. 2010. Establishing a missing link: Warm summers and winter snow cover promote shrub expansion into alpine tundra in Scandinavia. New Phytologist 186(4):890-899. https://doi.org/10.1111/j.1469-8137.2010.03223.x

IPCC (Intergovernmental Panel on Climate Change). 2007. Climate change 2007: Synthesis report. Contributions of Working Groups I, II and III to the Fourth Assessment Report of the Intergovernmental Panel on Climate Change. Core Writing Team, Pachauri, R.K., and Reisinger, A., eds. Geneva, Switzerland: IPCC.

Jia, G.J., Epstein, H.E., and Walker, D.A. 2006. Spatial heterogeneity of tundra vegetation response to recent temperature changes. Global Change Biology 12(1):42 - 55 . https://doi.org/10.1111/j.1365-2486.2005.01079.x

Johnson, L.A. 1981. Revegetation and selected terrain disturbances along the Trans-Alaska Pipeline, 1975-1978. CRREL Report 81-12. Hanover, New Hampshire: Cold Regions Research and Engineering Laboratory.

- 1987. Management of northern gravel sites for successful reclamation: A review. Arctic and Alpine Research 19(4): $530-536$.

Jorgenson, M.T. 1997. Patterns and rates of, and factors affecting natural recovery on land disturbed by oil development in Arctic Alaska. In: Crawford, R.M., ed. Disturbance and recovery in Arctic lands: An ecological perspective. Dordrecht: Springer. $421-442$.

Jorgenson, M.T., Shur, Y.L., and Pullman, E.R. 2006. Abrupt increase in permafrost degradation in Arctic Alaska. Geophysical Research Letters 33(2), L02503. https://doi.org/10.1029/2005GL024960

Jorgenson, M.T., Romanovsky, V., Harden, J., Shur, Y., O’Donnell, J., Schuur, E.A.G., Kanevskiy, M., and Marchenko, S. 2010. Resilience and vulnerability of permafrost to climate change. Canadian Journal of Forest Research 40(7):1219-1236. https://doi.org/10.1139/x10-060

Jorgenson, M.T., Marcot, B.G., Swanson, D.K., Jorgenson, J.C., and DeGange, A.R. 2015. Projected changes in diverse ecosystems from climate warming and biophysical drivers in northwest Alaska. Climatic Change 130(2):131-144.

https://doi.org/10.1007/s10584-014-1302-1
Lawson, D.E. 1986. Response of permafrost terrain to disturbance: A synthesis of observations from northern Alaska, U.S.A. Arctic and Alpine Research 18(1):1-17.

https://doi.org/10.2307/1551209

Lloyd, A.H., Yoshikawa, K., Fastie, C.L., Hinzman, L., and Fraver, M. 2003. Effects of permafrost degradation on woody vegetation at Arctic treeline on the Seward Peninsula, Alaska. Permafrost and Periglacial Processes 14(2):93-101. https://doi.org/10.1002/ppp.446

Martin, A.C., Jeffers, E.S., Petrokofsky, G., Myers-Smith, I., and Macias-Fauria, M. 2017. Shrub growth and expansion in the Arctic tundra: An assessment of controlling factors using an evidence-based approach. Environmental Research Letters 12(8), 085007. https://doi.org/10.1088/1748-9326/aa7989

Myers-Smith, I.H., and Hik, D.S. 2017. Climate warming as a driver of tundra shrubline advance. Journal of Ecology 106(2):547-560. https://doi.org/10.1111/1365-2745.12817

Myers-Smith, I.H., Forbes, B.C., Wilmking, M., Hallinger, M., Lantz, T., Blok, D., Tape, K.D., et al. 2011a. Shrub expansion in tundra ecosystems: Dynamics, impacts and research priorities. Environmental Research Letters 6(4), 045509. https://doi.org/Artn 04550910.1088/1748-9326/6/4/045509

Myers-Smith, I.H., Hik, D.S., Kennedy, C., Cooley, D., Johnstone, J.F., Kenney, A.J., and Krebs, C.J. 2011b. Expansion of canopyforming willows over the twentieth century on Herschel Island, Yukon Territory, Canada. AMBIO 40(6):610-623.

https://doi.org/10.1007/s13280-011-0168-y

Myers-Smith, I.H., Elmendorf, S.C., Beck, P.S.A., Wilmking, M., Hallinger, M., Blok, D., Tape, K.D., et al. 2015. Climate sensitivity of shrub growth across the tundra biome. Nature Climate Change 5(9):887-891. https://doi.org/10.1038/Nclimate2697

Naito, A.T., and Cairns, D.M. 2011a. Patterns and processes of global shrub expansion. Progress in Physical Geography 35(4):423-442. https://doi.org/10.1177/0309133311403538

- 2011b. Relationships between Arctic shrub dynamics and topographically derived hydrologic characteristics. Environmental Research Letters 6(4), 045506. https://doi.org/10.1088/1748-9326/6/4/045506

- 2015. Patterns of shrub expansion in Alaskan Arctic river corridors suggest phase transition. Ecology and Evolution 5(1):87-101. https://doi.org/10.1002/ece3.1341

NRC (National Research Council). 2003. Cumulative environmental effects of oil and gas activities on Alaska's North Slope. Washington, D.C.: National Academies Press.

Pearson, R.G., Phillips, S.J., Loranty, M.M., Beck, P.S.A., Damoulas, T., Knight, S.J., and Goetz, S.J. 2013. Shifts in Arctic vegetation and associated feedbacks under climate change. Nature Climate Change 3(7):673-677. https://doi.org/10.1038/nclimate1858 
Raynolds, M.K., and Cooper, D.J. 2016. Pre-ABoVE: Arctic Alaska vegetation, geobotanical, physiographic data, 1993-2005. Oak Ridge, Tennessee: ORNL Distributed Active Archive Center for Biogeochemical Dynamics.

https://doi.org/10.3334/ornldaac/1353

Raynolds, M.K., Walker, D.A., Ambrosius, K.J., Brown, J., Everett, K.R., Kanevskiy, M., Kofinas, G.P., Romanovsky, V.E., Shur, Y., and Webber, P.J. 2014. Cumulative geoecological effects of 62 years of infrastructure and climate change in ice-rich permafrost landscapes, Prudhoe Bay Oilfield, Alaska. Global Change Biology 20(4):1211-1224.

https://doi.org/10.1111/gcb.12500

Reynolds, J.F., and Tenhunen, J.D., eds. 1996. Landscape function and disturbance in Arctic tundra. Ecological Studies, Vol. 120. Berlin: Springer-Verlag. https://doi.org/10.1007/978-3-662-01145-4

Shur, Y.L., and Jorgenson, M.T. 2007. Patterns of permafrost formation and degradation in relation to climate and ecosystems. Permafrost and Periglacial Processes 18(1):7-19. https://doi.org/10.1002/ppp.582

Stow, D., Petersen, A., Hope, A., Engstrom, R., and Coulter, L. 2007. Greenness trends of Arctic tundra vegetation in the 1990s: Comparison of two NDVI data sets from NOAA AVHRR systems. International Journal of Remote Sensing 28(21):4807-4822. https://doi.org/10.1080/01431160701264284

Sturm, M., Racine, C., and Tape, K. 2001. Climate change: Increasing shrub abundance in the Arctic. Nature 411(6837):546-547.

https://doi.org/10.1038/35079180
Swann, A.L., Fung, I.Y., Levis, S., Bonan, G.B., and Doney, S.C. 2010. Changes in Arctic vegetation amplify high-latitude warming through the greenhouse effect. Proceedings of the National Academy of Sciences 107(4):1295-1300.

https://doi.org/10.1073/pnas.0913846107

Tape, K.D., Sturm, M., and Racine, C. 2006. The evidence for shrub expansion in northern Alaska and the Pan-Arctic. Global Change Biology 12(4):686-702. https://doi.org/10.1111/j.1365-2486.2006.01128.x

Walker, D.A., and Walker, M.D. 1991. History and pattern of disturbance in Alaskan Arctic terrestrial ecosystems: A hierarchical approach to analysing landscape change. Journal of Applied Ecology 28(1):244-276.

https://doi.org/10.2307/2404128

Walker, D.A., Webber, P.J., Binnian, E.F., Everett, K.R., Lederer, N.D., Nordstrand, E.A., and Walker, M.D. 1987a. Cumulative impacts of oil fields on northern Alaskan landscapes. Science 238(4828):757-761. https://doi.org/10.1126/science.238.4828.757

Walker, D.A., Cate D., Brown, J., and Racine, C. 1987b. Disturbance and recovery of Arctic Alaskan tundra terrain: A review of recent investigations. CRREL Report 87-11. Hanover, New Hampshire: Cold Regions Research and Engineering Laboratory.

Yi, S., Woo, M.-K., and Arain, M.A. 2007. Impacts of peat and vegetation on permafrost degradation under climate warming. Geophysical Research Letters 34(16), L16504.

https://doi.org/10.1029/2007GL030550 